\title{
EMPOWERING PASIR MULYA VILLAGE COMMUNITY IN SELF-SUPPORTING VILLAGE INFRASTRUCTURE DEVELOPMENT
}

\author{
Caroline Maretha Sujana, Oki Setyandito, Putri Arumsari, Irpan Hidayat, Eduari Prahara, Adelia \\ Nataadmadja \\ Bina Nusantara University, Indonesia. \\ Caroline.sujana@yahoo.com
}

\begin{abstract}
Indonesia Government from the outset emphasized the importance of implementing labor-intensive programs using local village human resources. This program should be carried out as much as possible by the local villagers themselves and not by using the contractors because it would conflict with the principle of opening employment opportunities for its citizens. One of the programs is implemented in Pasir Mulya Village. Some improvements to the village facilities that will be carried out are the construction of cultural buildings, slopes stability improvement, and road improvement. Base on preliminary study, it was obtained the importance of equipping villagers who involved in the project with project management techniques such as budget planning techniques, leading and motivating a project team, the importance of teamwork and communication in a team. By conducting project management and team-building training, infrastructure development by local villagers can run effectively.
\end{abstract}

Keywords: Project Management, Labor-Intensive Programs, Training, Teamwork

\section{INTRODUCTION}

Since the existence of the National Community Development Program (Program Nasional Pemberdayaan Masyarakat, PNPM Mandiri Program) conducted in 2015, a lot of work has been done in developing a village. Pasir Mulya Village is one of the villages that have the potential for mountain tourism and coffee-producing in Indonesia. Pasir Mulya village is located in Bandung regency, West Java, resided in the highlands with land contours up and down and some access roads are still a path without pavement.

Sustainable village development efforts have been carried out in the last two years by Binus University such as revamping clean water facilities, developing small and medium scale entrepreneurship, training in emergency response to natural disasters (Setyanto et al., 2018). The next development plans are the construction of a cultural building that will support tourism programs, revamping access roads and slope strengthening. This development uses the 2018 Village Funding (Dana Desa), targeting the absorbing of as many village workers as possible to encourage poverty alleviation. One of the programs organized by the Indonesian government is the Labor Intensive Program (BUMDES Directory, 2018).

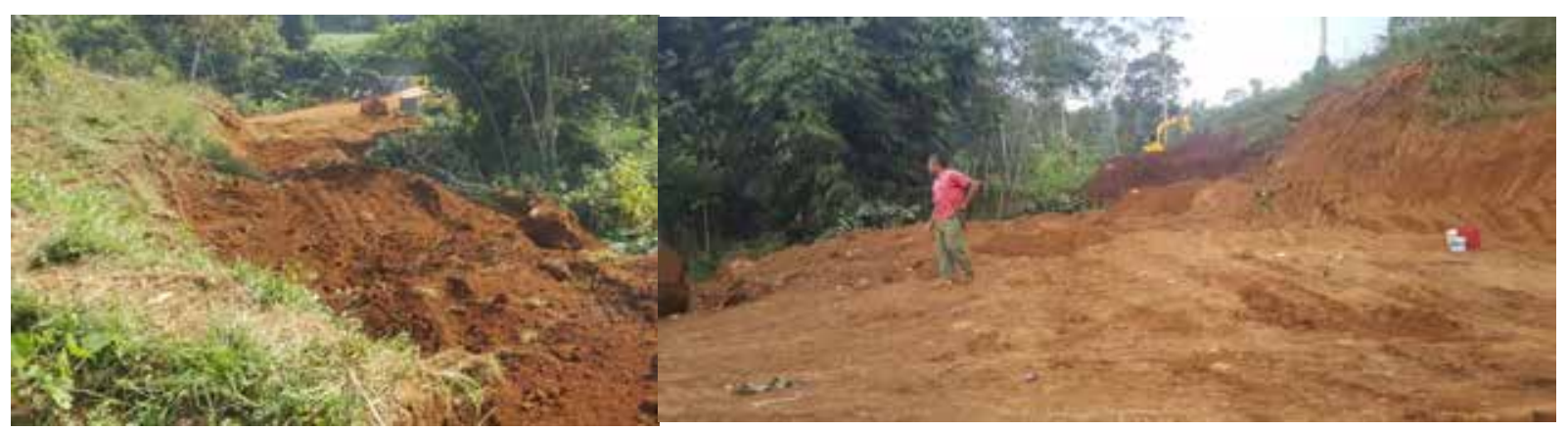

Picture 1. Road and slope conditions to be improved

The Indonesia Government from the outset emphasized the importance of implementing labor-intensive programs with village human resources. This program should be carried out as much as possible by the villagers themselves and not by contractors outside the village because it would conflict with the principle of opening employment opportunities for its citizens. The development of supporting infrastructure is carried out in a selfmanaged manner by gathering residents to reduce costs. The lack of experience in the project led to a demand for briefing residents about construction project management such as budgeting the construction project cost, the art of leading and motivating the project team, the importance of cooperation and communication in construction 
projects. This paper seeks to describe efforts to empower local communities in infrastructure development carried out by improving the project management skills of the Pasir Mulya community.

Project management is the art of directing and coordinating human and material resources throughout the life of a project by using modern management techniques to achieve predetermined objectives of scope, cost, time, quality and participation satisfaction (Santos, 2017). Project management is necessitated to support the success of a construction project. Construction participants must be able to make detailed budget planning which constitutes material, equipment and labor costs.

Furthermore, to direct and coordinate workers involved in projects, skills in leading and motivating subordinates are needed. According to Yukl (2006), leadership is a process to influence others, to make agreements about what needs to be done and how the task is carried out effectively, as well as processes to facilitate individual and collective efforts to achieve shared goals. According to Robbins (2003), leadership is the ability to influence a group towards the achievement of a goal. Yang (2011) alleged that the leadership style of a construction project manager will influence teamwork which will ultimately influence the success of the project.

The ability to lead can be affected by developing it in several ways including (1) formal training, (2) development activities, (3) personal activities. Training is usually designed for middle and lower class managers rather than for upper-class managers and usually emphasizes the skills needed to do the current job. The training is carried out with various techniques such as: giving behavioral examples, case discussions, business games, and simulations.

Awareness of the importance of communication and cooperation also needs to be instilled in each party involved. Team members need to be able to work well together as a team to successfully achieve the project goal (Lepine et al, 2008, McEwan et al, 2017) suggest that teamwork training should incorporate experiential activities that provide participants with more active ways of learning and practicing teamwork. These may include various workshops-style exercises that involve all team members, such as working through case studies of how units can improve teamwork, watching and critiquing video vignettes of teams optimal displaying versus suboptimal teamwork, discussing and setting teamwork- related goals and action plans, or other activities that help stimulate critical thinking and active learning of effective teamwork.

\section{METHOD}

This research begins with the identification of problems at an early stage. By applying the method of implementing self-management, the skills of local citizens in implementing, managing projects need to be improved. The technique of preparing the project implementation budget is taught only to citizens who act as project executors, accompanied by the provision of books and budgeting planning computer programs for them.

Capacity building in leadership, teamwork, and communication is achieved by accommodating training and team building. Community involvement in leadership and team-building activities will aid the understanding of theory better than teaching. The training is done by forming small groups that participate in the game to get things done together without communication and with communication.

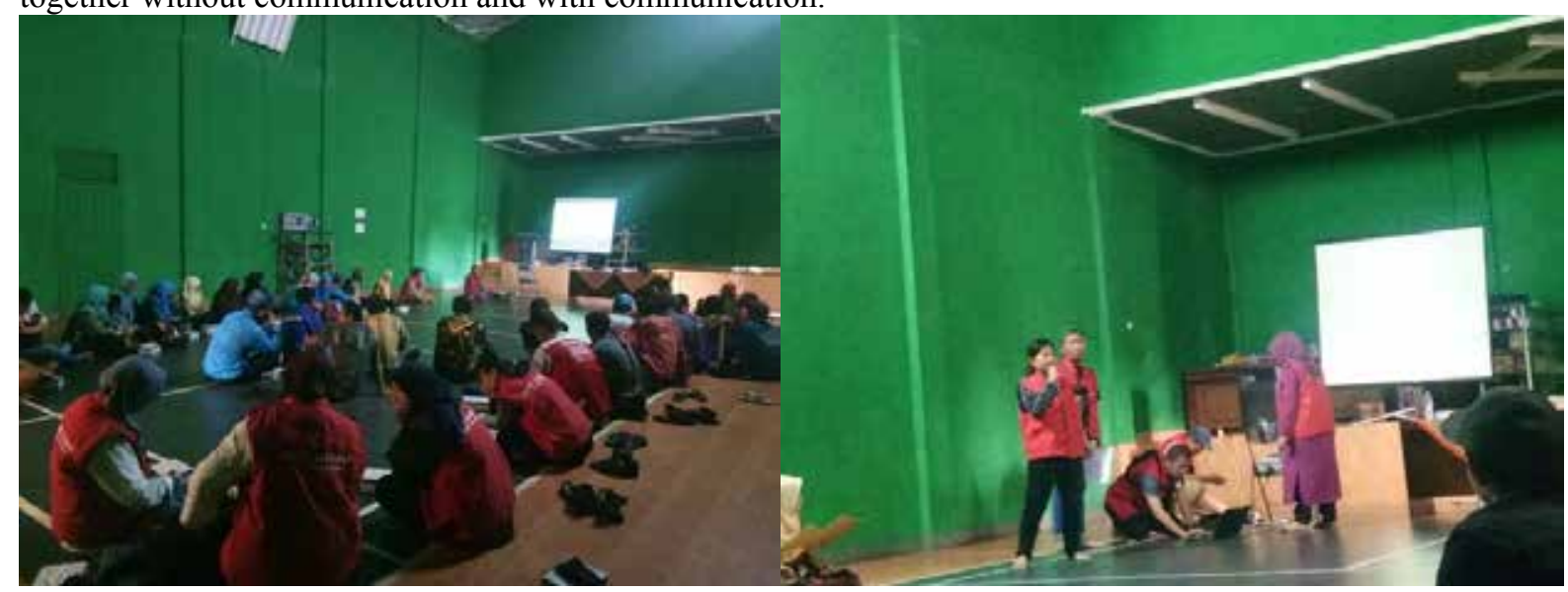

Picture 2. Team building and leadership training 


\section{RESULT AND DISCUSSION}

This research is a follow-up study that has been done beforehand by Setyandito etc. (2018), which is a Binus University program in community development. The program was carried out thoroughly starting with a preliminary study of what was needed in the village of Pasir Mulya, followed by assisting citizens in designing roads, pavement slopes, and simple cultural buildings.

After the design phase had completed, equipping local communities with construction management is very important so that they can manage the project and the costs obtained effectively. Training on leadership and teamwork can be easily understood by involving citizens in an activity/game about team building and leadership and using simple language that people can understand.

From the feedback obtained from residents after the event, the short training can improve villagers' understanding of the importance of collaboration and communication in project implementation and improve project management in the form of the ability to plan project budgets. Currently, the construction of a cultural building, revamping access roads and slope strengthening development activities are in the implementation stage.

\section{CONCLUSION}

The conclusions of this paper are as follows:

1. Community empowerment is very effective in village development. By providing a little of skill regarding construction management, the work done by residents will be more effective.

2. Training on leadership and teamwork can be easily understood by involving citizens in an activity/game about team building and leadership and using simple language that can be understood by citizens.

3. This community empowerment program in Pasir Mulya village can then be used as a pilot program to developing other villages

\section{REFERENCES}

BUMDES Directory (2018). 11 Prinsip Kerja Program Padat Karya. http://www.berdesa.com/11-prinsip-kerjaprogram-padat-karya/

Santos, J. M. D. (2017). What is construction project management https://project-management.com/what-isconstruction-project-management/

Lepine JA, Piccolo RF, Jackson CL, Mathieu JE, Saul JR. (2008). A Meta-Analysis Of Teamwork Processes: Tests Of A Multidimensional Model And Relationships With Team Effectiveness Criteria. Personnel Psychology.;61(2): 273-307.

Rousseau V, Aubé C, Savoie A. (2006). Teamwork behaviors: A review and an integration of frameworks. Small Group Research.;37(5): 540-70.

McEwan, D., Ruissen, G. R., Eys, M. A., Zumbo, B.D., Beauchamp, M.R. (2017). The Effectiveness of Teamwork Training on Teamwork Behaviors and Team Performance: A Systematic Review and Meta-Analysis of Controlled Interventions. journals plos.

Setyandito, O; Hidayat, I., Arumsari, P., Nataadmadja, A. Juliastuti (2018). Development of simple infrastructure to enhance sustainable development in Pasir Mulya Tourism Village. ICCD. 1(1).

Yukl, Gary (2006). Leadership in organization, Edisi ke 6, Pearson Practice Hall, USA.

Robbins, S.P. (2003). Organizational Behavio, Tenth Edition, Prentice Hall, Singapore.

Yang, Li Ren, Huang, Chung Fah, Wu, Kun-Shan (2011). The association among project manager's leadership style, teamwork and project success, International Journal of Project Management ,29, 258-267. 